


\title{
The ecological component of agrotourism development under the COVID-19 pandemic
}

\author{
DOI: https://doi.org/10.46398/cuestpol.3969.53
}

\author{
Roman Oleksenko * \\ Stanislav Bilohur ** \\ Nina Rybalchenko *** \\ Iryna Verkhovod **** \\ Halina Harbar *****
}

\begin{abstract}
The study was conducted to identify the environmental component in the development of agrotourism and its impact on the psychological state of society in the COVID-19 pandemic. The experience of European countries shows the environmental, economic, and social benefits of agrotourism. The methodological basis of the study is the general scientific methods of cognition and social processes (analysis, synthesis, generalization, classification) together with sociological methods of obtaining empirical data. The National Tourism Organization of Ukraine has declared 2020 as the year of green rural tourism, an important component from which agrotourism arises. It is concluded that, la peculiarity of the development of agrotourism in Ukraine at the current stage is the acquisition of innovative forms of organization according to the growing needs of consumers, the efficient use of the natural, ecological, socioeconomic, and historical-cultural potential of the territory and the achievement of the required level of profitability. The situation of crisis and instability is accompanied by the presence of uncertainty associated with the COVID-19 pandemic; the need to form the concept of tourism development 4.0; introduction of ICT and development of innovative technologies in agrotourism in rural areas; training of
\end{abstract} professionals in the field of agrotourism.

\footnotetext{
* Dmytro Motornyi Tavria State Agrotechnological University, Melitopol, Ukraine. ORCID ID: https:// orcid.org/oooo-0002-2171-514X.Email: roman.xdsl@ukr.net

** Alfred Nobel University, Dnipro, Ukraine. ORCID ID: https://orcid.org/oooo-ooo1-6755-7231. Email: bbilogur@gmail.com

*** Dmytro Motornyi Tavria State Agrotechnological University, Melitopol, Ukraine. ORCID ID: https:// orcid.org/oooo-0003-3358-2249. Email: ninarybka07@mail.com

****Bohdan Khmelnitsky Melitopol State Pedagogical University, Ukraine. ORCID ID: https://orcid. org/oooo-0002-9176-2574. Email: verkhovod-ira@ukr.net

**** Separate Subdivision "Mykolaiv Branch of the Kyiv National University of Culture and Arts", Mykolaiv, Ukraine. ORCID ID: https://orcid.org/oooo-0o03-4750-3361. Emal: garbargalina12@gmail.com
} 
Keywords: ecology; rural green tourism; sustainable community; development policies; COVID-19.

\section{El componente ecológico del desarrollo del agroturismo bajo la pandemia de COVID-19}

\section{Resumen}

El estudio se realizó para identificar el componente ambiental en el desarrollo del agroturismoy su impacto en el estado psicológico dela sociedad en la pandemia COVID-19. La experiencia de los países europeos muestra los beneficios ambientales, económicos y sociales del agroturismo. La base metodológica del estudio son los métodos científicos generales de cognición y procesos sociales (análisis, síntesis, generalización, clasificación) junto a métodos sociológicos de obtención de datos empíricos. La Organización Nacional de Turismo de Ucrania ha declarado 2020 como el año del turismo rural verde, un componente importante del cual surge el agroturismo. Se concluye que, la peculiaridad del desarrollo del agroturismo en Ucrania en la etapa actual es la adquisición de formas innovadoras de organización de acuerdo con las crecientes necesidades de los consumidores, el uso eficiente del potencial natural, ecológico, socioeconómico e histórico-cultural del territorio y el logro del nivel requerido de rentabilidad. La situación de crisis e inestabilidad se acompaña de la presencia de incertidumbre asociada a la pandemia de COVID-19; la necesidad de formar el concepto de desarrollo turístico 4.0; introducción de TIC y desarrollo de tecnologías innovadoras en agroturismo en áreas rurales; formación de profesionales en el campo del agroturismo.

Palabras clave: ecología; turismo verde rural; comunidad sostenible; politicas de desarrollo; COVID -19.

\section{Introduction}

With the development of economic activity and agritourism sphere the role and importance of ecological assessment and environmental control, which can have a negative impact on the state of the natural environment and public health, is increasing. That is why the great importance is to create a system of ecologically-oriented monitoring and management of human and natural resources, where the tourists' needs will be satisfied and taken into account to the maximum extent and the existing natural and tourist potential of specific regions will be fully used, created economically 
872 Roman Oleksenko, Stanislav Bilohur, Nina Rybalchenko, Iryna Verkhovod y Halina Harbar The ecological component of agrotourism development under the COVID-19 pandemic

favorable conditions for the local population and minimize negative processes in natural ecosystems, caused by both tourist and economic activities.

An important means of environmental assessment and environmental control is an environmental audit, which in modern conditions is included in all procedures (Bukanov et al., 2020). Because of the coronavirus pandemic, many countries, including Ukraine, were forced to close their borders for the first time in history. While now the world has emerged from the strict quarantine and is gradually beginning to open border crossings, Ukraine is advised to stay away from unnecessary travel and flights around the world. In such a reality, domestic tourism, including agrotourism, takes precedence among the recreation types. There is now a chance for farmers to provide a comfortable vacation for city dwellers, giving them the opportunity to spend their vacation within their area. Given this, agritourism can be a growth engine for the local economy. The positive impact of agrotourism in solving the socio-economic problems of rural areas lies in the expansion of rural employment not only in the production sector, but also in the service sector, in promoting the rural development, as well as stimulating the service sector development: transport, communication, trade, household services, recreation and entertainment and other establishments in rural areas.

\section{Objectives}

The main purpose of this study is to analyze the experience of agrotourism development models in European countries, as there is no clear program for the agro-tourism development, its importance for the economy, especially the regional one, has not been formed and justified. Therefore, the features of domestic agro-tourism were revealed, the impact of agrotourism on the environment was evaluated, we considered the prospects of agro-tourism development in conditions of coronavirus and postcoronavirus challenges justified the prospects of agro-tourism in Ukraine based on theoretical and analytical research. Methods - anthropological, axiological, phenomenological, ontological, systemic, structural-functional, phenomenological. Approaches - humanistic, cross-cultural, civilizational.

\section{Materials and methods}

The research methodology was based on the systematic approach and the dialectical method of cognition, monographic method, methods of analysis and synthesis. Synergetic approach, contributes to the analysis of the crisis moments COVID -19 and countries emerging from the crisis. The 
lack of concerted policies in the tourism sphere within regional formats can be a barrier to achieving synergistic effects in the development of digital tourism economy and achieving digital well-being and digital comfort of the tourism industry of agritourism, agroculture, agribusiness. Nonlinear complexity methodology plays a significant role in the implementation of digital management thinking and digital worldview of agritourism as an environmental development factor of economically depressed regions under the COVID-19 pandemic.

\section{Results and discussion}

As the analysis showed, the tourism industry around the world suffers losses on a global scale as a result of measures to counteract the COVID-19 pandemic and the uncertainty of future developments: $96 \%$ of tourist destinations around the world have received restrictions. According to the different data in 2020. There was a 58-78\% drop in international tourist revenues compared to last year. According to experts, the recovery of demand to the level of 2019 will last at least two years, while at the same time airlines will have to increase the travel cost by an average of $43-54 \%$. Domestic tourism also suffered significant losses: the loss of the tourism industry in Ukraine is estimated at more than 1,500,000,000 dollars. The late start of the resort and recreational season, as a result of the introduction of restrictive measures had a cumulative effect that has affected both the leisure and travel industry, and related industries - the hotel and restaurant business, transport (passenger transport), retail, entertainment industry and cultural institutions. In addition to current and projected losses, the Ukrainian Carpathian tourism sector this year also suffered from low demand for ski holidays as a result of abnormally warm winter.

At the same time, the situation should be seen not only as a problem, but also as an opportunity to bring the tourism sector in Ukraine to a qualitatively new level, primarily through domestic tourism. On the other hand, the leading tourist countries of the Black Sea region (Romania, Bulgaria, Turkey) have made an emphasis in 2020 precisely on the domestic tourism development, not only calling on citizens to rest at domestic resorts, but also implementing incentive measures. This experience is certainly worthy of emulation, the more so that travel restrictions imposed by states to prevent the spread of COVID-19, the drop in incomes of citizens due to the economic crisis and recession have the potential to increase demand for holidays within Ukraine. And if we also take into account the need to minimize contacts in order to keep away from the disease and the possibility of rapid self-isolation in case of a threat, then the main driver of the preservation and revival of the industry is tourism in rural areas. 
It is also worth taking into account that the outbreak of the COVID-19 coronavirus disease had a negative impact on people's psychological state and mental balance - research on the pandemic and quarantine psychological impact on human life is ongoing. Obviously, each personality has individual characteristics of reacting to crisis situations, which depend on both the level of socio-economic development and the personal maturity itself (Okoro et al., 2020), (Durodié, 2020).

The results of a study by domestic scientists show a wide range of psychological consequences that the COVID-19 outbreak can lead to, including the appearance of new psychiatric symptoms in those who do not have mental illness and the deterioration of those who already suffer from such illnesses (Stepanov, 2018). An outbreak of coronavirus disease causes societal psychological reactions such as tension, anxiety and fear, loss of reference points and plans for the future, can also lead to post-traumatic stress disorder, depression, exacerbation of psychopathological symptoms and psychological problems. As a result of the pandemic, city dwellers have become isolated from nature and society through daily changes in living and working conditions. In their daily lives there is a growing psychological burden and the number of stressful situations.

Parks and squares cannot satisfy the need for relaxation with the opportunity to stay one-on-one with nature, especially since they have been closed due to the spread of the virus. That is why it is quite normal to want to get out of the city. The countryside attracts people in different ways: a special experience of life, sightseeing, buying unique local goods and organic products, immersion in pristine nature, recreation and just the peace and quiet that is so much missing in modern metropolitan areas. Therefore, agrotourism (as well as rural green tourism in general) is a way out of the situation, and because there is no need to cross the border, it is also materially more profitable (Musina et al., 2012).

A characteristic feature of agro-tourism is its environmental friendliness, soft impact on the environment. That is why the terms «rural ecotourism», «Agro-ecotourism», «rural green tourism», «green tourism» are used. On the other hand, tourists are most attracted to nature and the possibility of life in it through the countryside and agricultural production. We have to admit that the development of agrotourism in our country is still quite spontaneous and to some extent spontaneous. Terminological uncertainty complicates the situation (agritourism, green tourism, rural, ecological tourism are often used as synonyms), then - and legal. Even government leaders and business managers who support this direction of tourist activity, sometimes differently understand these terms, giving them a different meaning. It is quite natural that such terminological and legal uncertainty impedes creation of full-fledged economic development strategy of this tourism type, restrains programs of support and assistance (Pinchuk, 2009). 
In general, this situation hinders the development of tourism activities in rural areas. Without the purpose of this study to solve this problem, we clarify only that we understand agrotourism as a kind of rural green tourism (a generalized name for tourism in rural areas), which is part of green tourism (which also includes recreation in special recreational territories

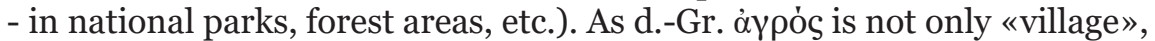
but also «a field», «arable land», «agrotourism» should be understood as a kind of rural tourism with farming elements (see «farm tourism» in German and Spanish models - tab. 1) (Kravets, 2007)

Table 1. Models for the development of green tourism

\begin{tabular}{|c|c|}
\hline $\begin{array}{c}\text { French } \\
\text { model }\end{array}$ & $\begin{array}{l}\text { 1) Various forms of classic rural green tourism, which varies } \\
\text { depending on the closeness to the sea; } \\
\text { 2) considerable attention is paid to the development of } \\
\text { gastronomic and wine tourism; } \\
\text { 3) Tourist accommodation forms are less about living on farms, } \\
\text { tourists are accommodated in cottages. }\end{array}$ \\
\hline $\begin{array}{c}\text { German } \\
\text { model }\end{array}$ & $\begin{array}{l}\text { 1) Accommodation and meals in farmhouses; } \\
\text { 2) Rural green tourism is intertwined with farm and event } \\
\text { tourism; } \\
\text { 3) Working on the land is allowed. }\end{array}$ \\
\hline $\begin{array}{l}\text { Italian } \\
\text { model }\end{array}$ & $\begin{array}{l}\text { 1) Rural green tourism combined with health restoration, } \\
\text { learning about gastronomy and local products, sports; } \\
\text { 2) accommodation of tourists in apartments; } \\
\text { 3) Tent camps are widespread. }\end{array}$ \\
\hline $\begin{array}{l}\text { Czech } \\
\text { model }\end{array}$ & $\begin{array}{l}\text { 1) Oriented to industrial regions and border regions with } \\
\text { conservation areas; } \\
\text { 2) is a budget recreation; } \\
\text { 3) Accommodation in farmhouses with elements of authentic } \\
\text { rural life. }\end{array}$ \\
\hline $\begin{array}{c}\text { Spanish } \\
\text { model }\end{array}$ & $\begin{array}{l}\text { 1) Recreation in the countryside, on the farm is widespread; } \\
\text { 2) familiarity with farming, gastronomy, caring for animals. }\end{array}$ \\
\hline $\begin{array}{l}\text { Polish } \\
\text { model }\end{array}$ & $\begin{array}{l}\text { 1) is characterized by a clear distinction of «tourist» farms: } \\
\text { for some it is the main and only business, for others it is an } \\
\text { additional income; } \\
\text { 2) accommodation facilities differ in cost and service quality. }\end{array}$ \\
\hline $\begin{array}{c}\text { Latvian } \\
\text { model }\end{array}$ & 1) Recreation with elements of tra \\
\hline
\end{tabular}


876 Roman Oleksenko, Stanislav Bilohur, Nina Rybalchenko, Iryna Verkhovod y Halina Harbar The ecological component of agrotourism development under the COVID-19 pandemic

In general, green tourism in Ukraine appeared as a concept 15-20 years ago, but now to this direction more attention, because of COVID-19 According to the project «Green Tourism» («Green Tourism»-2020: sometimes - as an option for «quarantine» solitude. Of this year, this direction of tourism has become more popular than in the past, but people also consider this recreation option as self-isolation in nature. The owners of the estates tell us that there are significantly more calls, including from former clients, and in general most estates are doing better than last year. Traditionally, the greatest influx of visitors is on weekends. Among the consumer priorities - the opportunity to stay by the water, recreation space, bath houses, a list of «activities» - archery, horseback riding, fishing, master classes in traditional crafts (painting, embroidery, pottery), etc. The Union of Rural Green Tourism (Ukrainian hospitable mansions, 2021), created in Ukraine in 1996, conducts information work and in every way helps in its promotion to the tourist services market.

The most active regions for the development of agrotourism are Zakarpattya, Ivano-Frankivsk, Vinnitsa, Kiev, Lviv and Poltava. The main agro-tourism centers in Ukraine gravitate to the recreational areas: clean rivers, forests, sea coast, lakes and reservoirs, as well as the architectural complexes of towns and villages. The leader in the development of rural green tourism in general is traditionally the Carpathian region (IvanoFrankivsk, Transcarpathian and Lviv region), but because of the high incidence of disease in the western regions, as well as inclement weather and flooding, Ukrainians discover other regions. Recently, the number of estates in Chernivtsi, Volyn, Kiev, Cherkasy and Vinnytsia regions is increasing. More and more popular is agritourism in Eastern Ukraine, especially in Zaporizhzhia, Kirovograd, Dnipropetrovsk and Donetsk regions. However, if the European market, according to estimates of the European Federation of Farmers and Rural Tourism (EuroGites), there are about 2 million beds, in Ukraine it is about 150 thousand potential participants of green tourism. Officially invite to stay in the countryside only 37 farmsteads in seven regions of the country. The Union of Rural Tourism Promotion believes that this figure for Ukraine is quite successful (Ministry of Ecology and Natural Resources)

In order to assess the environmental condition of the territory, it is necessary to conduct an environmental audit, which will help to assess the impact on certain land areas or a particular territory to identify priorities for their further development, development of programs, specific actions for environmental rehabilitation of contaminated areas, as well as to justify the ways of rational economic activity.

The result of ecological audit of agro-tourism objects is to find the ways of their ecological development. Such ways can include: minimization of anthropogenic impacts, waste utilization, the use of energy- and resource- 
saving technologies and alternative energy sources, the introduction of water reuse and clean-up systems, reducing noise and chemical pollution from tourist transport, the development of new tourism types, which are aimed at a high environmental security.

Figure 1. Actions of the international projects and programs in Ukraine

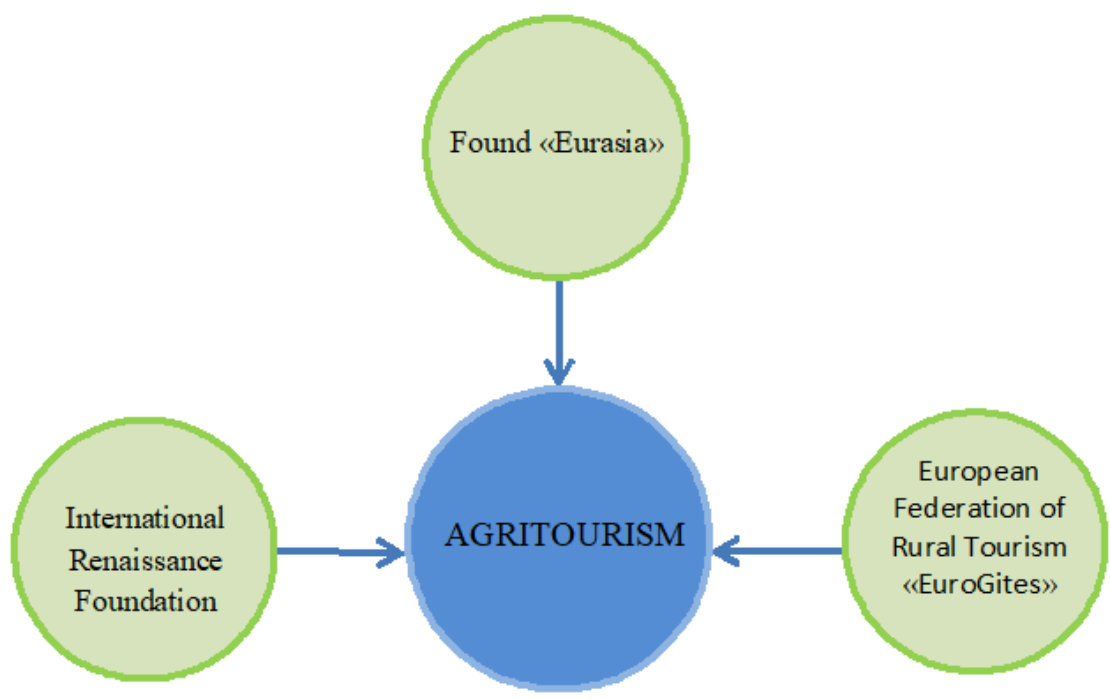

Source: own elaboration.

Figure 1 shows the agrotourism support due to the action of international projects and programs. Today's realities of agrotourism is a side practice in rural areas and more often is an additional form of farming or private subsidiary farming activities. Note that in many European countries agrotourism also initially formed as an auxiliary sub-sector of agriculture and only over time began to turn into an independent and competitive service sector, acting today as the main activity of the rural population. Therefore, the extreme conditions of coronavirus infection spreading can be a prerequisite for the rapid development and establishment of agrotourism, which contributes to the restoration of the Ukrainian tourism sector as a whole. In general, the agrotourism development as a catalyst for economic development and rapid tourist routes recovery, the use of creative digital economy and digital management as factors of tourism business sustainable development. The territorial tourist potential covers the whole set of natural, ethno-cultural and socio-historical resources, as well as the 
available economic and communication infrastructure of the territories, which can be a prerequisite for the development of agrotourism, influence the dynamics of tourism business development as a basis for sustainable development.

Quite original, in our opinion, within the framework of ecological development of agrotourism, is the proposal for tourists to plant trees or on a separate plot of land with the possibility of partial or complete care of them, with the consumer can be offered a lease agreement of a certain plot for an agreed period, at the end of which he could receive an agreed part of the harvest or products in ready (canned) form. This would allow the tourist to stay in the countryside for a long period of time, and for the owner of the farmstead to guarantee the demand for the tourist product. To increase the interest of tourists in the product of agritourism, it is possible to offer planting coniferous trees in the forest, forest plantations, which will increase the level of environmental awareness of tourists, improve the ecological condition of the area, reduce soil erosion, and for communities will be an opportunity to generate income from the sale of planting material.

This approach is widespread in many European countries. A special OECD project «Going Digital: Transformation for Growth and Prosperity» (2017) includes 7 vectors of digitalization 1. Increase without significant costs. 2. Customization with the needs of the consumer. 3. Speed and momentum challenges. 4. Intangible capital and new sources of value creation. 5. Transformation of space. 6. Empowerment. 7. Platforms and ecosystems of digitalization. Activities to shape the concept of sustainable tourism development goals in the EU and Ukraine: 1) the restoration of agrotourism tourism activity opens the prospect of transformation through innovation, digitalization, sustainability, partnerships, restoration of consumer confidence, mitigation of socio-economic impacts; 2) implementation of sustainable development goals for reducing inequalities between and within countries due to loss of tourism income;

3) Ensuring a more stable, inclusive, resource-efficient development of agritourism, ensuring women's employment and strengthening trust and partnerships in all tourism activities primarily ensuring inclusiveness and reducing inequalities; 4) increasing the competitive capacity of the tourism sector, promoting innovation and digitalization of the tourism ecosystem, promoting inclusive green tourism; 5) strengthening coordination and partnerships to transform tourism and achieve the Sustainable Goals 6) providing jobs directly to the agritourism sector as a result of the Covid-19 pandemic, developing the hotel and transport sector (air and sea travel crisis), cruise tourism sector, developing all types of green, rural agritourism; 6) protecting women, youth and creative industries workers most affected by the Covid-19 pandemic in rural areas; 8) forming a road map for making agritourism environmentally safe and inclusive. 


\section{Conclusion}

On the basis of the study and analysis of agrotourism development models, the features of domestic agrotourism are revealed. Taking into account the results of the conceptual approaches analysis to the definition of agritourism as a significant component of rural green tourism and its characteristics, the paper proves that it is one of the most promising directions to bring domestic tourism out of crisis. Besides, agritourism is an effective tool to help the local population to leave the fields without leaving the village, because it provides commercial and employment opportunities for communities that face the growing problem of local livelihoods. In the absence of these rural business opportunities, migration to urban areas will continue to grow, which will further strain Ukrainian urban infrastructure and social services. The basic meanings of agrotourism ecologization lies in the preservation and restoration of natural areas that are vulnerable and environmentally unsustainable to negative impacts; prevention and elimination of potential and existing sources of negative impacts on the environment in the tourism and economic activities; coordinated planning of tourist activity with other economic activities; introduction of environmentally soft technologies in the tourism industry; To avoid negative impacts on the environment by evenly distributing tourists (in time and space) and the creation of alternative recreational areas.

The implementation of the proposed recommendations will promote mutually beneficial cooperation between the rural green tourism market actors in the region and local authorities, the preservation of the environment and the national natural parks' uniqueness and sustainable rural development. Environmental component of agrotourism development in the COVID-19 pandemic: focus on nature; people; sustainable and safe rural environment formation; balance of interests, development principles and opportunities; accessibility and profitability of services and rural services; integration, openness and interaction; continuous improvement of management quality; emphasis on economic efficiency; long-term solutions priority over short-term; application of creative digital technologies in rural areas.

The formation of the creative village space - human capital development through the development of agrotourism, which is based on improving digital literacy of the rural population, skills development of specialists in the field of information and communication creative technologies and creative thinking development. Rural tourism market is one of the largest and most dynamic markets in the world, based on the development of the ecological component of agrotourism. That is why it is necessary to diversify the creative digital technologies in the tourism business in rural areas, as tourism is a sufficiently stable and significant item for state economic income. The World Travel and Tourism Council (WTTC) predicts that in 
2024 tourism revenues will be about 298,000,000, and the official analysts forecast that tourism revenues will grow by $3.3 \%$ in the next decade.

According to the World Travel and Tourism Council (WTTC), tourism in the EU will occupy 23\% of the nation's leading industries. For further development of agrotourism, creative digital technologies in the tourism business should be updated and reformatted to be competitive even after COVID-19. For this purpose, it is necessary to: mitigate the socio-economic impact of the crisis on rural employment in the COVID-19 pandemic; support the development of domestic and regional agritourism; diversify the use of creative technologies in agritourism to improve competitiveness and its resource efficiency; strengthen coordination and partnerships to make agritourism a sustainable development factor; promote employment preservation in the agritourism sector as a result of the economic and social impacts of COVID-19; promote confidence building through protection and safety in all types of tourism activities; promote social partnership between the state, business and civil society.

\section{Bibliographic References}

BUKANOV, Hryhorii; SKAKOVSKA, Svitlana; KULBAKA, Viktor; SYTNICHENKO, Olena; KULBAKA, Olesia. 2020. "Training and implementation of the environmental, economic, and legal development policy of the regions: main practice-oriented approaches" In: Cuestiones Políticas. Vol. 38, No. 67, pp. 200-214. Available online. In: https://doi.org/10.46398/cuestpol.382e.15. Date of consultation: 16/09/2020.

DURODIÉ Bill, 2020. "Handling uncertainty and ambiguity in the COVID-19 pandemic" In: Psychological Trauma: Theory, Research, Practice, and Policy. Available online. In: https://doi. org/10.1037/traoo00713. Date of consultation: 16/09/2020.

HORBAN, Yuliia. 2020. "Green Tourism" -2020: Sometimes - As an Option For "Quarantine" Solitude. Available online. Is: https://www.ukrinform.ua/rubric-tourism/3058062-zelenijturizm2020-inodi-ak-variant-dla-karantinnogo-usamitnenna. html. Date of consultation: 16/09/2020.

KRAVETS, Oleksandr. 2007. Rural tourism - hospitality traditions that bring profit. Available online. Is: https://artkavun.kherson.ua/uaslskij_turizm_tradits_gostinnost_jak_prinosjat_pributok.htm. Date of consultation: 16/09/2020. 
MINISTRY OF ECOLOGY AND NATURAL RESOURCES OF UKRAINE. 2020. Available online. Is: https://menr.gov.ua. Date of consultation: 16/09/2020.

MUSINA, Ludmila; YAMCHUK, Anatolii; KVASHA, Tetiana. 2012. Mutual influence of economy and natural environment in the modern world: policy, strategies, technologies. Monograph K. Kiev, Ukraine.

OKORO, Johnson; ODIONYE, Tobechukwu; NWEZE, Benedicta; ONUOHA, Martins; EZEONWUKA Chinenye; OWOH Jude; NKIRE, Joel. 2020. "COVID-19 pandemic, psychological response to quarantine, and knowledge of the disease among inmates in a Nigerian custodial center" In: Emerald Open Research. Available online. In: https://emeraldopenresearch.com/articles/2-26. Date of consultation: 16/09/2020.

PINCHUK, Tetiana. 2009. "Agrotourism as a form of entrepreneurship in rural areas" In: Scientific herald of UzhNU”: Series «Economics». No. 28, pp. 49-53.

STEPANOV, Victor. 2018. "Rural green tourism in Ukraine: problems and prospects" In: Actual problems of public administration. Vol. 1, No. 53, pp. 1-5.

UKRAINIAN HOSPITABLE MANSIONS. 2021. Available online. Is: https://www.greentour.com.ua. Date of consultation: 16/09/2020. 

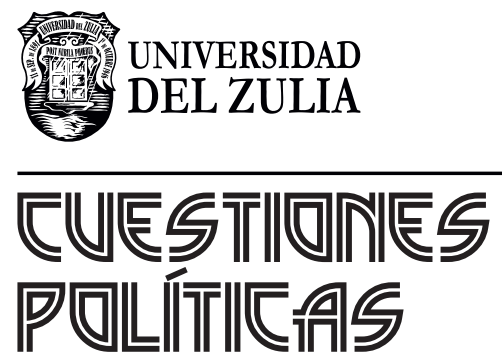

Vol.39 No 69

Esta revista fue editada en formato digital y publicada en julio de 2021, por el Fondo Editorial Serbiluz, Universidad del Zulia. Maracaibo-Venezuela 